\title{
Kinetics of aggregation and structural properties of proteins in inclusion bodies studied by Fourier transform infrared spectroscopy Antonino Natalello*1, Diletta Ami ${ }^{1}$, Pietro Gatti-Lafranconi ${ }^{1}$, Ario de Marco ${ }^{2}$, Marina Lotti ${ }^{1}$ and Silvia Maria Doglia ${ }^{1}$
} \author{
Scientific Core Facilities, Mayerhofstr. 1, D-69117, Heidelberg, Germany \\ * Corresponding author \\ from The 4th Recombinant Protein Production Meeting: a comparative view on host physiology \\ Barcelona, Spain. 2I-23 September 2006 \\ Published: 10 October 2006 \\ Microbial Cell Factories 2006, 5(Suppl I):P97 doi:10.II86/1475-2859-5-SI-P97
}

Address: ${ }^{1}$ Department of Biotechnology and Biosciences, University of Milano-Bicocca, Piazza della Scienza 2, 20126 Milano, Italy and ${ }^{2}$ EMBL

(c) 2006 Natalello et al; licensee BioMed Central Ltd.

\section{Background}

Protein aggregation plays a crucial role in medical sciences and in biotechnology, as it occurs in several diseases and in the expression of recombinant proteins in bacterial cells in the form of inclusion bodies (IBs). Interestingly, it has been suggested that the presence of native-like structures within IBs [1-4] improves the efficiency of refolding protocols that employ mild solubilization methods [5]. This property could also explain the residual enzymatic activity of recombinant proteins in IBs, with possible applications in biocatalysis [6].

As recombinant protein production in bacteria is a central issue in biotechnology, it would be instructive to monitor the kinetics of protein aggregation and the extent of native-like secondary structures within IBs.

\section{Results}

We will present a new Fourier transform infrared spectroscopy (FT-IR) approach to study the aggregation of recombinant proteins in E. coli in the form of aggregates of increasing complexity. The method enables to monitor the kinetics of aggregate formation within intact cells in a rapid and non invasive way and to obtain structural information on proteins within IBs. We will report results on four recombinant proteins: human growth hormone (h$\mathrm{GH}$ ), human interferon-alpha-2b (IFN-alpha-2b) [4,7], Pseudomonas fragi lipase [3], and green fluorescent protein - glutathione S-transferase fusion protein (GFP-GST) [8].
Kinetics of aggregate formation was investigated at different production temperatures. The rate of protein aggregation, monitored by the marker band of aggregation in the FT-IR absorption spectrum (Amide I band), was found to increase with the raising of production temperature. Furthermore, the protein expression in its soluble and insoluble fraction was also evaluated by the analysis of the FTIR spectrum, in excellent agreement with SDS-PAGE analysis.

To obtain structural information on protein aggregates, extracted IBs were also studied in the Amide I absorption region. Two structural features were observed, namely the presence of native-like residual structures and the intermolecular $\beta$-sheet interaction of proteins within IBs.

Interestingly, for the same protein the residual native-like structures in IBs were found to change with the level of expression. Therefore, by modulating the culture conditions, the extent of native-like structures in IBs can be optimised with useful applications in biotechnology.

Furthermore, additional structural features were obtained by the comparison of the FT-IR spectra of the native form, IBs and thermal aggregates for the same protein.

\section{Conclusion}

This FT-IR analysis offers a simple and rapid method to monitor in vivo the development of aggregates formed by 
heterologous proteins and the effect of culture condition modification on the process. Furthermore, the method indicates that aggregating proteins modify at different extent their secondary structures from native $\alpha$-helices and intramolecular $\beta$-sheets to intermolecular $\beta$-sheets typical of amorphous aggregates and fibrils.

\section{Acknowledgements}

This work was supported by INFM (Istituto Nazionale Fisica della Materia) grant to S.M.D. The support of F.A.R. (Fondo di Ateneo per la Ricerca)

grants to S.M.D. and M.L. is also acknowledged.

\section{References}

I. Oberg K, Chrunyk BA, Wetzel R, Fink AL: Native-like secondary structure in interleukin-I beta inclusion bodies by attenuated total reflectance FTIR. Biochemistry 1994, 33:2628-2634.

2. Przybycien TM, Dunn JP, Valax P, Georgiou G: Secondary structure characterization of beta-lactamase inclusion bodies. Protein Eng 1994, 7:131-136.

3. Ami D, Natalello A, Gatti-Lafranconi P, Lotti M, Doglia SM: Kinetics of inclusion body formation studied in intact cells by FT-IR spectroscopy. FEBS Lett 2005, 579:3433-3436.

4. Ami D, Natalello A, Taylor G, Tonon G, Doglia SM: Structural analysis of protein inclusion bodies by Fourier transform infrared microspectroscopy. Biochim Biophys Acta 2006 in press.

5. Patra AK, Mukhopadhyay R, Mukhija R, Krishnan A, Garg LC, Panda AK: Optimization of inclusion body solubilization and renaturation of recombinant human growth hormone from Escherichia coli. Protein Expr Purif 2000, 18:182-192.

6. Garcia-Fruitos E, Gonzalez-Montalban N, Morell M, Vera A, Ferraz RM, Aris A, Ventura S, Villaverde A: Aggregation as bacterial inclusion bodies does not imply inactivation of enzymes and fluorescent proteins. Microb Cell Fact 2005, 4:27.

7. Ami D, Bonecchi L, Calì S, Orsini G, Tonon G, Doglia SM: FT-IR study of heterologous protein expression in recombinant Escherichia coli strains. Biochim Biophys Acta 2003, 1624:6-10.

8. Schrödel A, de Marco A: Characterization of the aggregates formed during recombinant protein expression in bacteria. BMC Biochemistry 2005, 6:10.

Publish with Biomed Central and every scientist can read your work free of charge

"BioMed Central will be the most significant development for disseminating the results of biomedical research in our lifetime. "

Sir Paul Nurse, Cancer Research UK

Your research papers will be:

- available free of charge to the entire biomedical community

- peer reviewed and published immediately upon acceptance

- cited in PubMed and archived on PubMed Central

- yours - you keep the copyright 